1964

\title{
Alpha Amylase Development in Embryos of Crassostrea virginica
}

Robert E. Black

Virginia Institute of Marine Science

E.T. Pengelley

Follow this and additional works at: https://scholarworks.wm.edu/vimsarticles

Part of the Aquaculture and Fisheries Commons

\section{Recommended Citation}

Black, Robert E. and Pengelley, E.T., Alpha Amylase Development in Embryos of Crassostrea virginica (1964). Biological Bulletin, 126(2), 199-204.

https://scholarworks.wm.edu/vimsarticles/2108

This Article is brought to you for free and open access by the Virginia Institute of Marine Science at W\&M ScholarWorks. It has been accepted for inclusion in VIMS Articles by an authorized administrator of W\&M ScholarWorks. For more information, please contact scholarworks@wm.edu. 


\title{
ALPHA AMYLASE DEVELOPMENT IN EMBRYOS OF CRASSOSTREA VIRGINICA ${ }^{1}$
}

\author{
ROBERT E. BLACK AND E. T. PENGELLEY 2 \\ Department of Biology and Virginia Institute of Marine Science, ${ }^{3}$ College of \\ William and Mary, Williamsburg, Virginia
}

Numerous investigations of changes in enzyme activity during development have been made during recent years. Such studies have been reviewed by Moog (1958, 1959), Løvtrup (1959) and Brachet (1960). Relatively few quantitative investigations have been made of enzymes in embryonic invertebrates; we therefore have little knowledge of enzymic changes which are temporally associated with visible morphogenetic events in these embryos.

In this paper, data on the levels of alpha amylase in several developmental stages of the oyster are presented. This enzyme is present in considerable concentration in the crystalline style, a mucoprotein rod secreted in a diverticulum of the intestine of adult pelecypods and some gastropods (Yonge, 1926; Prosser and Brown, 1961). It was therefore of interest to determine whether any change in amylase activity accompanied the development of the larval intestine. It was also of some interest to determine whether a high activity of this enzyme would be found in larvae which had not yet begun feeding, since the levels of digestive enzymes in various adult animals sometimes depend on the presence of appropriate foods ( $c f$. van Weel, 1961 ; Prosser and Brown, 1961).

\section{Materials AND Methods}

Adult oysters were collected from the Rappahannock River and stored in trays suspended from the laboratory pier at Gloucester Point, Virginia. The salinity at the laboratory varies during the summer from approximately 18 to $22 \mathrm{ppm}$. For collecting gametes, portions of the gonads were removed from the adults and shaken briefly in pasteurized river water having a salinity of $20 \mathrm{ppm}$. The eggs were washed by settling and fertilized. Eggs from different adults were kept separate until the percentage of fertilization could be checked at the time of first cleavage. In all batches of eggs used, more than $90 \%$ of the eggs were fertilized and developed normally. The eggs were cultured at $28^{\circ} \mathrm{C}$. in a rotating flask suspended in a Warburg apparatus. The concentration of larvae was kept at about $5 \times 10^{8}$ per liter. The culture water contained 250 units of penicillin and 250 micrograms of streptomycin per milliliter.

Before setting up each larval culture, 5 aliquots were diluted, and two secondary aliquots of $1.0 \mathrm{ml}$. were counted from each of the primary samples. At the

1 Supported by a grant (GB-710) from the National Science Foundation.

2 Present address: Division of Biological Sciences, University of California, Riverside, California.

${ }^{3}$ Contribution No. 154. 
appropriate developmental stage three large aliquots of embryos were collected by centrifugation, washed in pasteurized river water, and homogenized at $0^{\circ} \mathrm{C}$. in $2 \% \mathrm{NaCl}$ containing $0.02 \mathrm{M}$ phosphate buffer at $\mathrm{pH}$ 6.2. Homogenization was accomplished by the use of an all-glass Tenbroeck homogenizer of small capacity.

Amylase was assayed by the method of Sumner, as described by Bernfeld (1955). For each assay $0.1 \mathrm{ml}$. of appropriately diluted homogenate was mixed at zero time with $0.4 \mathrm{ml}$. of $1 \%$ potato starch (also in $\mathrm{NaCl}$ phosphate buffer) in a test tube of $10 \mathrm{ml}$. capacity. After incubation at $28^{\circ} \mathrm{C}$. for 30 minutes the reaction was stopped by the addition of $1.0 \mathrm{ml}$. of 3,5-dinitrosalicylate reagent ( $1 \%$ 3,5-dinitrosalicylate in $0.4 \mathrm{~N} \mathrm{NaOH}$ containing 30\% Rochelle salt). The tubes were boiled for 5 minutes, and $2.0 \mathrm{ml}$. of water were added after cooling. After 5 minutes of centrifugation at about $3000 \mathrm{~g}$, the absorbance was determined at 540 millimicrons in a Beckman DU spectrophotometer. Standards containing known amounts of maltose were treated in an identical manner in each experiment.

Enzyme assays were always run at two levels of homogenate concentration; this provided continuous assurance that reaction rates were proportional to the amount of homogenate added. In preliminary experiments the digestion reaction was found to be nearly linear for 30 minutes.

For determinations of the extent of bacterial contamination, aliquots were removed from embryo cultures, from whole antibiotic-free embryos washed at the time of enzyme assay, and from embryo homogenates. These aliquots were spread on nutritive sea-water agar plates and incubated five days at $20^{\circ} \mathrm{C}$. before counting.

In one experiment larvae of 17 and 37 hours were fixed in Bouin's fluid at $70^{\circ} \mathrm{C}$., embedded in paraffin, and sectioned at 5-7 microns. Sections were stained with Delafield's hematoxylin in order to determine in a gross way the degree of formation of the larval intestine at these times, which correspond to the first detected appearance and point of maximum activity of amylase.

Determinations of total protein were made in some instances on aliquots of homogenate. These were done by the method of Lowry et al. (1951).

\section{RESUlts}

\section{Development of the larval intestine}

At $28^{\circ} \mathrm{C}$. the "trochophore" stage is reached in about 8 hours, at which time the endoderm is a cellular mass which fills most of the blastocoele. There is a slight invagination at the blastopore, representing the archenteron and presumptive mouth. At 17 hours the archenteron cavity extends about one-half the distance between the blastopore and the site of the future anus. At this time the larva is a straight-hinge veliger. Observations on whole mounts and living embryos after 17 hours indicate that the intestinal tract is a complete, straight tube by 22 hours of development at this temperature. Sections at 17 hours show that ciliation is evident on the cells that lie in the medial part of the archenteron. By 37 hours the gut is tripartite and exhibits extensive ciliation and some muscular movement. No evidence for a style sac or other diverticulum was found in embryos up to 48 hours of age. Embryos of 37 hours and older were frequently found to possess a small mass of highly refractive material, which did not stain with hematoxylin, 


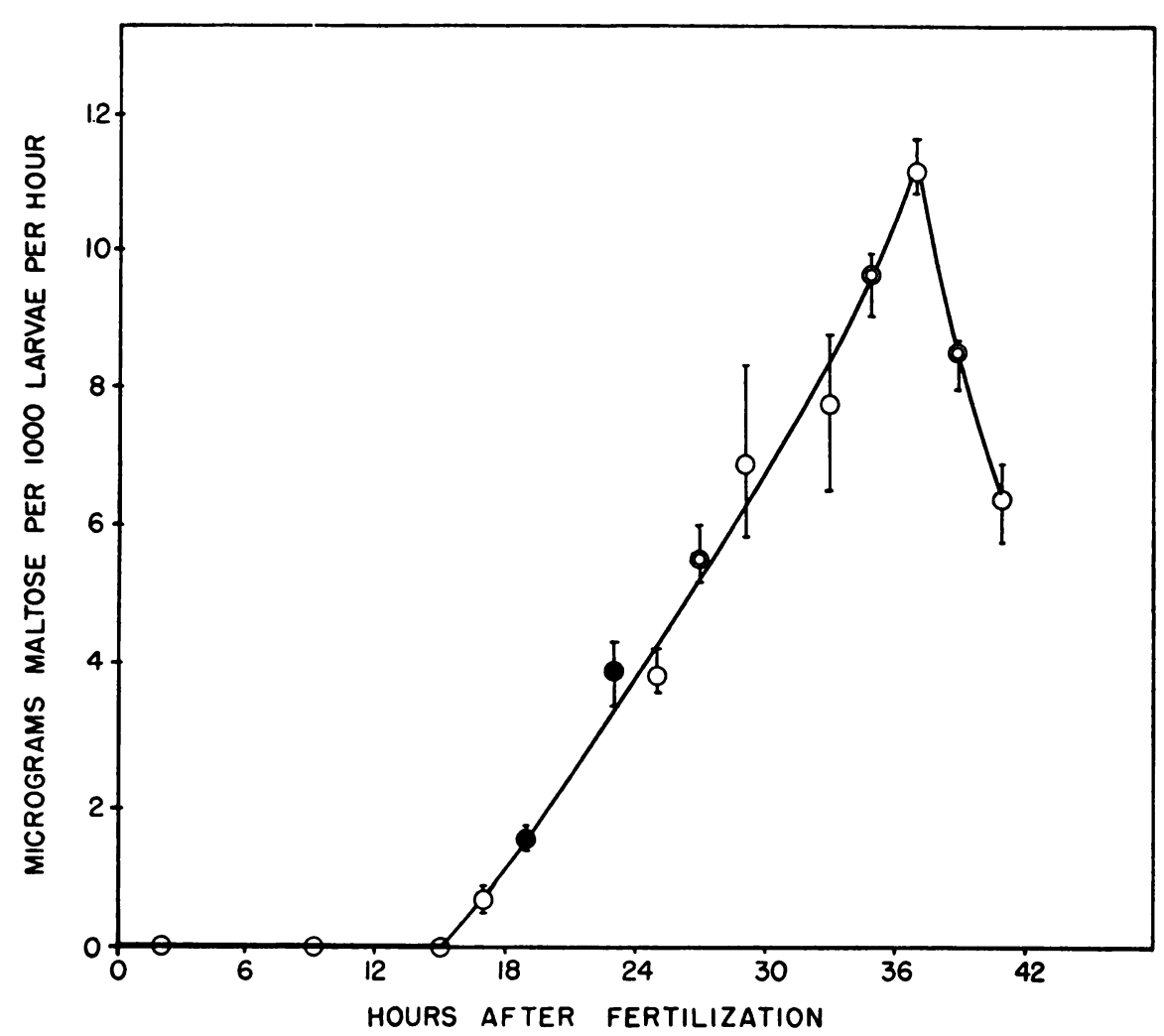

FIGURE 1. Alpha amylase activity in homogenates of developing oyster larvae, grown at $28^{\circ} \mathrm{C}$. The different symbols represent different batches of eggs. The range of values obtained is shown for each stage. The incubation mixture contained $0.8 \%$ potato starch, $2 \% \mathrm{NaCl}$, and $0.02 M$ sodium phosphate, $\mathrm{pH} 6.2$.

in the lumen of the midgut. This may represent a larval precursor to the crystalline style.

\section{Amylase activity in homogenates}

Data on enzyme activity in homogenates are presented in Figure 1 . The enzyme was not detected before 17 hours of development, even with homogenate concentrations of $50 \%$ in the assay mixtures, and with incubation times up to three hours. The increase in activity between 17 and 37 hours is nearly linear. Extrapolation of this activity curve shows that the increase probably begins at about 15 hours. After 37 hours a sharp decrease in activity occurs. The decrease is evidently not a result of the release of the enzyme into the medium, since no amylase activity could be detected in water in which concentrated suspensions of 37-hour embryos had been incubated for two hours.

The average values obtained in five determinations of total protein in the homogenates are as follows $\left(\times 10^{-10}\right.$ grams per egg $):$ unfertilized eggs, $2.6 \pm 0.6$; 


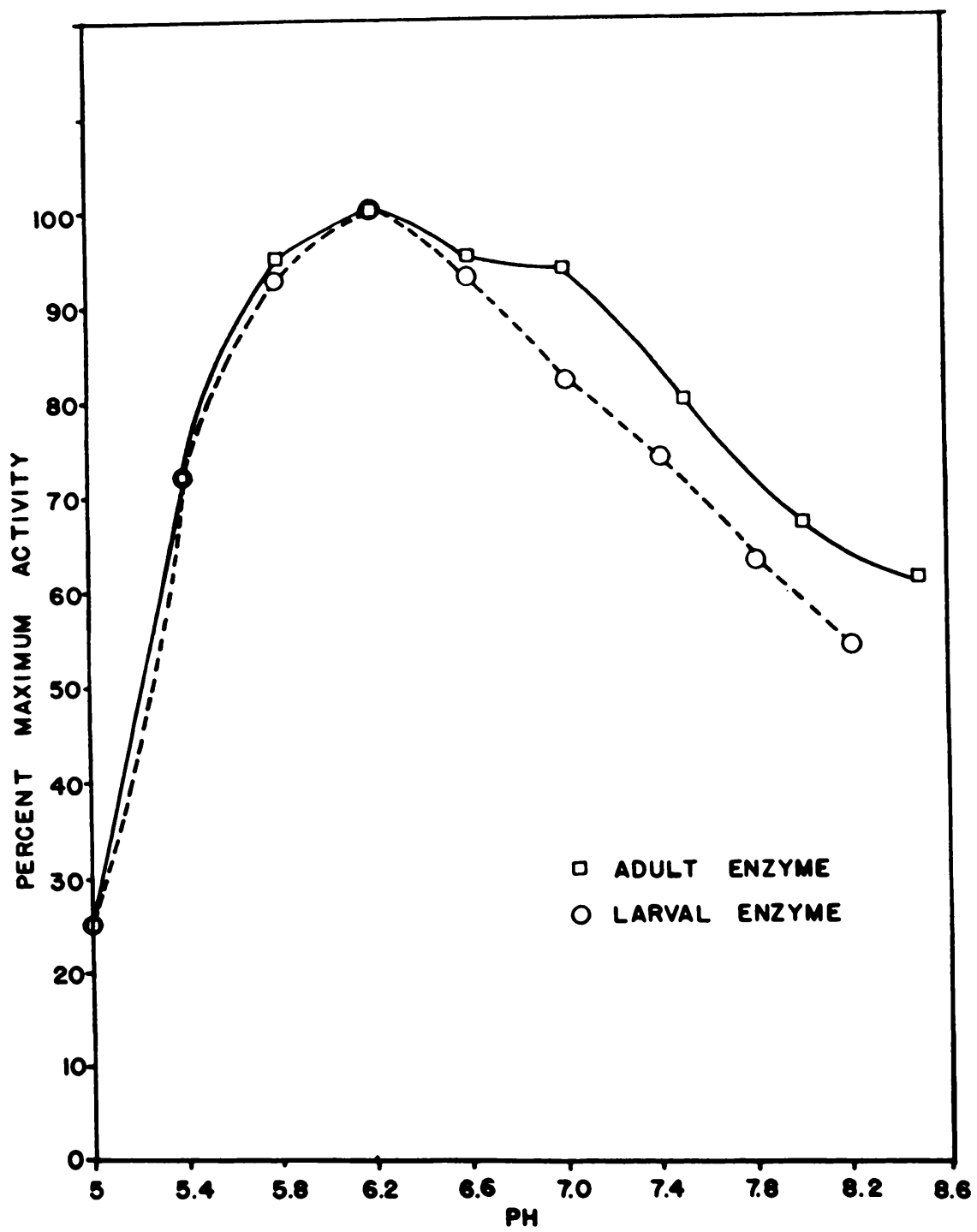

FIGURE 2. The effect of $\mathrm{pH}$ on the activity of amylase from 36-hour veligers and from adult crystalline styles of the oyster. All preparations contained $0.8 \%$ potato starch, $2 \%$ $\mathrm{NaCl}, 0.02 M$ sodium acetate and $0.02 M$ sodium phosphate.

20-hour veligers, $1.7 \pm 0.5 ; 48$-hour veligers, $1.8 \pm 0.7$. The apparent decrease in protein during the first 20 hours may be only artifactual, since it was difficult to correct for the differences in turbidity of the homogenates at the different stages. In any case the changes in enzyme activity are not reflected by any simultaneous changes in total protein. 
The bacterial contamination in the cultures appeared to be low in all experiments. The plate counts varied from 0 to 0.06 bacterium per embryo when live, "antibiotic-free" embryos were plated. Counts made from the homogenates gave values of 50 to 10,000 per ml.; by comparison the homogenates contained approximately $10^{6}$ embryos per ml. There was no correlation between the bacterial counts in homogenates and the enzyme activity in these, and it was concluded that the extent of contamination was insufficient to affect the level of enzyme activity in the assay mixtures.

\section{Properties of larval and adult amylases}

It was of interest to compare the properties of the larval enzyme with those of amylase extracted from adult styles, with respect to $\mathrm{pH}$ optimum, substrate specificity, and energy of activation. Crystalline styles were dissected from adults, homogenized in buffered saline solution, and centrifuged at $10,000 \mathrm{~g}$ for 5 minutes to remove insoluble, mucus-like material. Data obtained on enzyme activities in acetate-phosphate buffers of different $\mathrm{pH}$ are presented in Figure 2. The optimum $\mathrm{pH}$ for the enzyme from both sources is 6.2. A second optimum is shown by the adult enzyme at 7.0 ; the crystalline style may therefore contain a second amylase which is not present in the larva. Assays of enzyme activity with different substrates indicated that the enzyme from both sources digested these at the following relative rates: potato starch 1.00 , "soluble" starch $0.7-0.8$, and glycogen $0.3-0.5$. The temperature coefficients for digestion of potato starch were found to be as follows: larval enzyme, $10-20^{\circ}$ C., 2.29 ; $20-30^{\circ}, 1.76$; adult enzyme, $10-20^{\circ}, 2.76 ; 20-30^{\circ}, 1.85$. The average energy of activation for the larval enzyme is therefore 11,845 calories per mole while that for the adult is 14,700 calories. Since neither enzyme was purified, this difference probably does not represent an actual chemical difference in the two enzymes. Both values are reasonably close to the value of 13,350 calories per mole, which has been reported for human salivary amylase (Bernfeld, 1955).

\section{Discussion}

It is apparent from Figure 1 that enzyme production or activation in the larva must decrease abruptly or stop at 37 hours. It appears possible that the decrease could result from extracellular digestion of amylase by proteolytic enzymes in the intestine; however, if enzyme production or activation were continuing at the same time, one would expect a more gradual decline in activity. It would be of interest to determine whether enzyme activity could be maintained at a high level under conditions in which amino acids and substrates are fed to the larvae. It is conceivable that the decrease in enzyme activity is a result of exhaustion of the yolk supply in those cells which produce the enzyme; on the other hand, the activity of amylase might be controlled by some intracellular feedback mechanism.

The properties of larval and adult amylases are quite similar, and there is little reason to suppose that the veliger contains a different protein from that of the adult. Amylase is a relatively simple protein which has been crystallized from several sources, and it appears feasible to obtain highly purified preparations from both larval and adult oysters. A further characterization of purified enzyme from 
both sources might reveal subtle differences which were not detected in the present study.

The data indicate that amylase reaches a high level of activity prior to the intake of any food by the larva. Amylase may be one of a number of digestive enzymes which are produced or activated simultaneously just before the feeding stage is reached. Such increases in amylase and other digestive enzymes have also been reported in the amphibian, Siredon ( $c f$. Løvtrup, 1959). It seems likely that the survival of larvae such as those of the oyster, which have little yolk reserve, will depend to a large extent on the types and specificities of the digestive enzymes which are present at the time that feeding begins. From the point of view of both the developmental physiologist and the ecologist it would be of value to determine what internal and external factors influence the activities of these enzymes during endodermal differentiation and during the early period of feeding.

The authors are indebted to Mr. Robert Mentzer for his technical assistance during this investigation.

\section{Sum MARY}

Alpha amylase activity is absent from developmental stages of the oyster up to the straight-hinge veliger. Its development after this stage parallels the development of the intestine. After reaching a maximum at 37 hours, the enzyme drops sharply in activity, presumably because of starvation. The larval enzyme has the same $\mathrm{pH}$ optimum and substrate specificity as that of the adult, but the energy of activation is somewhat lower than that of the adult.

\section{LITERATURE CITED}

Bernfeld, P., 1955. Amylases, $\alpha$ and $\beta$. Methods in Enzymology, I: 149-158. Ed. by S. P. Colowick and N. O. Kaplan. Academic Press, New York.

Brachet, J., 1960. Biochemistry of Development. Pergamon Press, New York.

L фVTRUP, S., 1959. Biochemical indices of embryonic differentiation. In: Biochemistry of Morphogenesis, pp. 105-125. Proceedings of the Fourth International Congress of Biochemistry. Ed. by W. J. Nickerson. Pergamon Press, New York.

Lowry, O. H., N. J. Rosebrough, A. L. Farr and R. J. Randall, 1951. Protein measurement with the Folin phenol reagent. J. Biol. Chem., 193: 265-275.

Moog, F., 1958. Enzymes: formation and growth. In: Symposium on Embryonic Nutrition, pp. 87-102. Ed. by D. Rudnick. University of Chicago Press.

MooG, F., 1959. The adaptations of acid and alkaline phosphatases in development. In: Cell, Organism and Milieu, pp. 121-155. Ed. by D. Rudnick. Ronald Press, New York.

Prosser, C. L., AND F. A. Brown, Jr., 1961. Comparative Animal Physiology, p. 128. W. B. Saunders, Philadelphia.

VAN WEEL, P. B., 1961. The comparative physiology of digestion in molluscs. Amer. Zool., 1: 245-252.

Yonge, C. M., 1926. Structure and physiology of the organs of feeding and digestion in Ostrea edulis. J. Mar. Biol. Assoc., 14: 295-386. 